\title{
Peran Ruang Publik Terpadu Ramah Anak Bagi Anak Usia Dini
}

\author{
Putu Indah Lestari ${ }^{1} \bowtie$, Elizabeth Prima ${ }^{2}$ \\ Pendidikan Guru Pendidikan Anak Usia Dini, Universitas Dhyana Pura \\ DOI: $\underline{10.31004 / \text { obsesi.v4i1.396 }}$
}

\begin{abstract}
Abstrak
Pendidikan anak usia dini dilakukan melalui pemberian pengalaman, rangsangan, serta menyediakan lingkungan yang kondusif. Salah satu lingkungan belajar adalah Ruang Publik Terpadu Ramah Anak (RPTRA) yang memiliki karakteristik sebagai taman terbuka publik, wahana permainan dan tumbuh kembang anak, ruang terbuka hijau, serta sarana kegiatan sosial dilengkapi berbagai permainan menarik. RPTRA di Kota Denpasar yaitu Taman Lalu Lintas dan Taman Janggan. Penelitian ini bertujuan untuk menganalisa peran RPTRA sebagai lingkungan belajar bagi anak usia dini, pemanfaatan RPTRA bagi nilai perkembangan anak usia dini, serta model pembelajaran di luar kelas. Penelitian ini termasuk penelitian deskriptif menggunakan teknik oberservasi, wawancara, dan studi dokumen. Hasil penelitian ini adalah Taman Lalu Lintas dan Taman Janggan memberikan tempat bermain sambil belajar (edurecreation). Nilai edukasi di kedua taman antara lain perkembangan kognitif, fisik motorik, sosial budaya, emosional, dan intelektual. Sekolah TK/ PAUD memanfaatkan kedua taman untuk kegiatan pembelajaran di luar kelas sebagai salah satu model pembelajaran.
\end{abstract}

Kata Kunci: ruang publik terpadu ramah anak; anak usia dini; lingkungan belajar

\begin{abstract}
Early childhood education is propered through providing experience, stimulation, and providing a conducive environment. One of the learning environments are the Child Friendly Integrated Public Space (CFIPS) which has the characteristics of a public open park, an approach for children development, green open space, and social facilities equipped. The existing CFIPS in Denpasar are Traffic Park and Janggan Park. This study aims to analized the role of CFIPS as a learning environment for early childhood, knowing the use of CFIPS for the value of early childhood development, as well as learning models outside the classroom. This research includes descriptive research using observation techniques, interviews, and document studies. The results of this study are the Traffic Park and Taman Janggan provide a place to play while learning (edurecreation) that is used by the community including early childhood. The value of education in both parks includes cognitive, physical motor, socio-cultural, emotional and intellectual development. Kindergarten schools utilize in both parks for learning activities outside the classroom as a learning model.
\end{abstract}

Keywords: child friendly integrated public space, early childhood, learning environment.

Copyright (c) 2019 Putu Indah Lestari, Elizabeth Prima

$\square$ Corresponding author:

Email Address : indahlestari@undhirabali.ac.id

Received 17 December 2019, Accepted 24 December 2019, Published 27 December 2019 


\section{PENDAHULUAN}

Pendidikan merupakan upaya untuk menyiapkan generasi bangsa yang berkualitas dalam memasuki era globalisasi yang penuh dengan berbagai tantangan. Tujuan pembangunan nasional adalah mewujudkan masyarakat adil makmur yang merata material dan spiritual berdasarkan Pancasila. Salah satu bagian penting dalam komponen masyarakat Indonesia adalah anak karena anak adalah pemilik masa kini dan masa depan bangsa. Untuk itu, pengembangan anak khususnya anak usia dini secara menyeluruh mencakup kesehatan dasar, pengembangan emosi serta pendidikan (Latif, 2014)

Pemegang peranan penting dalam mewujudkan generasi bangsa yaitu pendidikan berkualitas, yang dimulai dari pendidikan anak usia dini (PAUD). Pendidikan Anak Usia Dini adalah jenjang pendidikan yang ditujukan bagi anak sejak lahir sampai usia 6 tahun yang dilakukan melalui pemberian rangsangan pendidikan untuk membantu pertumbuhan dan perkembangan jasmani dan rohani agar anak memiliki kesiapan dalam memasuki pendidikan lebih lanjut yang diselenggarakan pada jalur pendidikan formal, nonformal, dan informal (UU No 20 Tahun 2003, 2003). PAUD berfungsi menumbuhkembangkan seluruh potensi anak baik melalui kemampuan motorik, kognitif, sosial emosional, bahasa, nilai agama dan moral, ataupun melalui seni (Permendikbud Nomor 146, 2014). Segala bentuk kegiatan pendidikan anak usia dini dikembangkan dalam sistem pembelajaran harus terencana dengan baik sesuai dengan tingkat pencapaian anak. Pendidikan anak usia dini diarahkan untuk memfasilitasi tumbuh kembang anak secara sehat dan optimal sesusai dengan nilai, norma, dan harapan masyarakat. Pendidikan anak usia dini dilakukan melalui pemberian pengalaman, rangsangan yang maksimal, serta menyediakan lingkungan yang kondusif (Latif, 2014).

Penyelenggaraan pendidikan anak usia dini bertujuan untuk membentuk anak Indonesia yang berkualitas yaitu anak yang tumbuh dan berkembang sesuai dengan tingkat perkembanganya sehingga memiliki kesiapan yang optimal di dalam memasuki pendidikan dasar serta kehidupan selanjutnya. Selain itu pendidikan anak usia dini bertujuan untuk menyiapkan anak mencapai kesiapan belajar (akademik) di sekolah (Walujo \& Listyowati, 2017). Pembelajaran pada anak usia dini terjadi apabila terdapat interaksi antara peserta didik dengan pendidik, serta diikuti dengan sumber belajar yang memadai yang terdapat dalam lingkungan belajar sehingga terjadi perubahan perilaku-perilaku tertentu (Fadlillah, 2012). Desain pembelajaran usia 0-6 tahun dirancang sesuai dengan perkembangan anak secara holistik mulai dari penyusunan rencapa pelaksanaan pembelajaran, pemilihan sumber dan media pembelajaran, metode yang digunakan.

Pembelajaran merupakan kegiatan rekayasa supaya terjadi peristiwa belajar, maka penggubahan lingkungan dan sumber belajar di sini adalah terkait dengan upaya guru memfasilitasi siswa untuk berinteraksi dengan lingkungan dan sumber belajar tersebut (Santyasa, 2007). Menurut (Fadlillah, 2012) metode pembelajaran yang pada pendidikan anak usia dini antara lain: metode ceramah, metode tanya jawab, metode pembiasaan, metode keteladanan, metode bermain, metode bercerita, metode bernyanyi, metode pemecahan masalah, metode simulasi, dan metode karya wisata. Metode karya wisata yaitu suatu metode pembelajaran yang mengajak peserta didik ke suatu tempat tertentu untuk mempelajari sesuatu yang berkaitan dengan materi yang diajarkan. Metode karya wisata merupakan cara penyajian bahan pelajaran dengan membawa anak kepada objek yang akan dipelajari di luar kelas (Wondal, 2015). Metode karya wisata memberikan manfaat yaitu: a) merangasang minat terhadap sesuatu; b) memperluas informasi yang diperoleh; c) memberi pengalaman belajar secara langsung; d) menambah wawasan; e) memberikan perasaan menyenangkan; dan f) mempererat hubungan antara orang tua dan pendidik PAUD (Latif, 2014).

Metode karya wisata diterapkan berkaitan dengan materi-materi yang melibatkan anak secara langsung dan bersifat nyata dalam lingkungannya. Lingkungan belajar anak usia dini sebaiknya menyediakan fasilitas bermain anak yang menjadikan anak bebas untuk 
bergerak, berkreasi, menjelajah termasuk melakukan berbagai manipulasi sehingga anakanak mendapatkan beberapa perilaku baru dari aktivitasnya. Lingkungan belajar di dalam ruangan akan digunakan tempat belajar bagi anak-anak untuk mengasah berbagai potensinya. Kegiatan di lingkungan belajar luar ruangan tempat bermain anak (outdoor playground) merupakan bagian integral dari program pengembangan dan pembelajaran anak-anak. Penerapan metode karya wisata dalam pembelajaran bukan semata mengajak anak berwisata ke suatu tempat. Akan tetapi, mengajak anak belajar di luar kelas, mengetahui atau menyelidiki kebenaran pengetahuan yang didapat anak di dalam kelas (Yati, 2016)

Lingkungan belajar di luar ruangan menguntungkan dan efektif membantu perkembangan anak-anak yang memiliki kecerdasan jamak yang bervariasi, maka lingkungan belajar outdoor playground harus menjadi bagian yang perlu ditata dengan baik dan serius (Mariana, 2017). Ketika anak-anak bermain di luar, mereka menunjukkan ketertarikan serta rasa ingin tahu yang tinggi. Karena lingkungan di luar kelas selalu penuh kejutan dan kaya akan perubahan. Di luar kelas anak-anak dapat mempelajari berbagai hal serta mengoptimalkan semua aspek perkembangannya. Guru-guru pun dapat membantu anak dalam meningkatkan pertumbuhan mereka melalui program-program pembelajaran, yang dapat dievaluasi melalui pengamatan, atau pun berinteraksi langsung dengan anak (Mariana, 2017). Lingkungan belajar merupakan salah satu faktor kunci keberhasilan dalam membangun kemampuan dan perilaku anak-anak dan mengembangkan potensi kecerdasan anak. Implikasinya adalah bahwa lingkungan untuk anak-anak harus diberikan prioritas, terutama jika lingkungan tersebut adalah lingkungan belajar.

Salah satu lingkungan belajar bagi anak usia dini adalah Ruang Publik Terpadu Ramah Anak (RPTRA). Menurut (Hernowo \& Navastara, 2017) Ruang Publik Terpadu Ramah Anak (RPTRA) adalah ruang publik yang memiliki karakteristik sebagai taman terbuka publik, wahana permainan dan tumbuh kembang anak, bagian dari prasarana dan sarana kota layak anak, ruang terbuka hijau, dan sarana kegiatan sosial yang dilengkapi dengan berbagai permainan menarik, pengawasan CCTV, ruang perpustakaan, ruang laktasi, dan lainnya. RPTRA bertujuan untuk menyediakan tempat terjadinya berbagai kegiatan dan fungsi ruang publik terintegrasi, seperti bermain dan belajar untuk anak-anak, tempat interaksi sosial bagi warga, tempat konsultasi dan ruang informasi serta edukasi bagi warga.

Ruang terbuka publik sebagai wadah kegiatan yang mampu merangsang gerak anak dalam beraktifitas diluar ruang (Rizani et al., 2017). Ruang terbuka publik memiliki 3 jenis fungsi, yaitu fungsi ekologis untuk meningkatkan kualitas kesehatan lingkungan perkotaan, fungsi estetis/ arsitektural untuk menciptakan keindahan lingkungan perkotaan dan fungsi sosial sebagai tempat interaksi soial masyarakat dalam suatu kota. Untuk memenuhi fungsi sosial tersebut, maka ruang terbuka publik harus bersifat responsif, demokaratis dan bermakna. Ruang terbuka publik yang bersifat responsive adalah ruang yang dirancang dan diatur untuk melayani berbagai kebutuhan (needs) dari penggunanya. Kebutuhan dasar yang mempengaruhi kepuasan manusia dalam ruang terbuka publik antara lain kenyamanan, relaksasi, keterlibatan aktif dan keterlibatan pasif (Desti \& Prihastom, 2018).

Menurut Kementerian PPPA dalam (Desti \& Prihastom, 2018) kriteria ruang bermain ramah anak adalah sebagai berikut: a) mudah diakses oleh anak termasuk anak dengan disabilitas dan anak marjinal; b) tidak memungut biaya (gratis); c) bahan yang digunakan tidak membahayakan anak; d) tidak menggunakan tanaman berduri; e) terang benderang; f) sarana dan prasarana disesuaikan dengan kondisi anak, termasuk anak disabilitas; g) minimal $3 / 4$ area terdiri dari rumput/tanah; h) lingkungan aman dari bahaya sosial dan kekerasan; i) tersedia sarana pendukung menuju ke area permainan; j) tersedia SDM/ pengelola/ pengawas yang ramah anak; $\mathrm{k}$ ) tersedia tempat mencuci tangan dan toilet ramah anak; l) tersedia fasilitas pertolongan pertama pada kecelakaan; dan $\mathrm{m}$ ) lingkungan bebas dari sampah, polusi, lalu lintas dan bahaya fisik lainnya. Penataan dalam RPTRA tidak 
hanya menitik beratkan pada anak-anak namun juga mempertimbangkan keberadaan pelaku usaha masyarakat di sekitarnya (Prasetyo, Atma, \& Yogyakarta, 2019). Ruang-ruang kota yang ditata saling berkesinambungan ini beraneka ragam pendekatan dalam perencanaan dan pembangunannya. Tata guna lahan, sistem transportasi dan sistem jaringan merupakan tiga faktor utama dalam menata ruang kota (Anhusadar \& Islamiyah, 2019). Pembangunan RPTRA yang memenuhi aspek keamanan dan keselamatan anak ialah salah satu bentuk perwujudan pemenuhan indakator Kota Layak Aanak (Tarigan, 2018). Perencanaan Kota/Kabupaten Layak Anak (KLA) adalah salah satu upaya pemerintah, masyarakat, dan swasta dalam memenuhi hak-hak anak yang juga merupakan bagian dari komunitas (Herllina \& Nadiroh, 2018).

RPTRA yang ada di Kota Denpasar yaitu Taman Lalu Lintas dan Taman Janggan. Kedua taman ini dimanfaatkan warga masyarakat sebagai salah satu tempat untuk berekreasi keluarga. Tahun 2018, baru terdapat 18 sekolah dari 324 sekolah PAUD di Kota Denpasar yang memanfaatkan Taman Lalu Lintas untuk kegiatan pembelajaran (Dishub Kota Denpasar, 2019). Sementara itu, belum ada data pemanfaatan Taman Janggan bagi sekolah-sekolah PAUD di Kota Denpasar. Taman Janggan maupun Taman Lalu Lintas sebagai wahana permainan, untuk tumbuh dan kembangnya anak menjadi sarana kemitraan antara Pemda, sekolah, dan masyarakat dalam memenuhi hak anak serta menjadi sarana kegiatan sosial warga termasuk pengembangan pengetahuan dan keterampilan. Penelitian ini bertujuan untuk mengetahui peran RPTRA sebagai lingkungan belajar bagi anak usia dini; mengetahui nilai-nilai perkembangan anak usia dini yang diperoleh melalui pemenfaatan RPTRA; dan mengetahui pemanfaatan RPTRA sebagai model pembelajaran di luar kelas.

\section{METODOLOGI}

Penelitian ini termasuk penelitian deskriptif. Metode analisis data yang digunakan adalah metode analisis deskriptif kualitatif. Analisis ini bertujuan membuat deskripsi secara sistematis, faktual, dan akurat mengenai fakta-fakta suatu wilayah, dalam hal ini yaitu Ruang Publik Terpadu Ramah Anak Taman Lalu Lintas dan Taman Janggan sebagai salah satu alternatif pembelajaran di luar kelas. Pemilihan lokasi ini didasarkan pada fenomena tentang tempat tersebut dimanfaatkan oleh sekolah-sekolah PAUD sebagai kegiatan pembelajaran di luar kelas, selain itu pemilihan lokasi ini diambil berdasarkan banyaknya pengunjung yang memanfaatkan kedua taman. Keberadaan Ruang Publik Terpadu Ramah Anak (RPTRA) mendukung terwujudnya Kota Denpasar menjadi Kota Layak Anak. Teknik pengumpulan data yaitu: teknik observasi, teknik wawancara, dan teknik studi dokumen atau studi pustaka. Observasi dilakukan untuk mengamati fasilitas sarana dan prasarana dari Taman Lalu Lintas dan Taman Janggan yang bisa menunjang kegiatan anak. Sumber data primer diperoleh secara langsung dari hasil wawancara kepada Kepala Sekolah PAUD, Kepala Dinas Perhubungan Kota Denpasar, Kepala Dinas Perumahan, Kawasan Permukiman dan Pertanahan Kota Denpasar, serta masyarakat umum pengguna RPTRA. Sedangkan sumber data sekunder berupa berupa hasil penelitian, jurnal ilmiah, majalah, buku-buku, dan dokumen pengelolaan ruang publik terpadu ramah anak.

\section{HASIL DAN PEMBAHASAN}

\section{Taman Lalu Lintas}

Taman lalu didirikan tanggal 25 Februari 2013 yang digagas oleh Dinas Perhubungan Kota Denpasar, Jasa Raharja, dan Polresta Denpasar. Taman Lalu Lintas terletak di Jalan Gatot Subroto Tengah sebelah selatan Taman Kota Lumintang. Tujuan didirikannya Taman Lalu Lintas adalah untuk mengedukasi, etika, moral dan membudidayakan tertib berlalulintas. Taman Lalu Lintas menjadi miniatur sarana dan prasarana aspek keselamatan berlalu lintas. Taman Lalu Lintas difungsikan sebagai ajang edukasi kepada masyarakat 
terkait keselamatan dan ketertiban berlalu lintas khususnya sarana edukasi bagi anak-anak pendidikan anak usia dini hingga sekolah menengah atas. Taman Lalu Lintas dilengkapi fasilitas-fasilitas yang dapat mendukug program edukasi. Fasilitas yang ada di Taman Lalu Lintas antara lain: rambu-rambu, marka jalan, Zona Selamat Sekolah (ZoSS), traffic light, halte, trotoar, dan tempat penitipan sepeda. Berdasarkan hasil wawancara dengan Kepala Bidang Lalu Lintas Dinas Perhubungan Bapak Ketut Darsana, S.H, Taman Lalu Lintas dapat dimanfatkan sekolah-sekolah untuk mengedukasi siswa khususnya tertib berlalu lintas

“...dinas perhubungan telah menyiapkan Taman Lalu Lintas agar bisa dimanfaatkan sekolah untuk mengedukasi siswanya. Ketika akan melakukan kegiatan di Taman Lalu Lintas, pihak sekolah bisa bersurat ke kami, gratis tidak dipungut biaya. Selain sekolah, masyarakat bisa menfaatkan fasilitas publik ini untuk rekreasi...." (Wawancara, 19 Agustus 2019)

Lebih lanjut Darsana menyampaikan keunggulan dari Taman Lalu Lintas adalah salah satu tolak ukur dari masyarakat yang menguasai, mengerti, dan membudayakan tertib berlalu lintas di jalan raya. Keunggulan lainnya adalah Taman Lalu Lintas mengubah mindset masyarakat untuk mengetahui bahwa kehati-hatian, empati, dan keselamatan nomor satu di jalan raya. Kendala yang dihadapi Dinas Perhubungan Kota Denpasar dalam mengelola Taman Lalu Lintas adalah masyarakat pengunjung kurang menjaga ketertiban dan kebersihan area Taman Lalu Lintas. Taman Lalu Lintas diharapkan benar-benar menjadi edurecreation dari tertib berlalu lintas di jalan raya. Dengan edukasi di Taman Lalu Lintas, generasi muda menjadi pioner dalam tertib berlalu lintas.
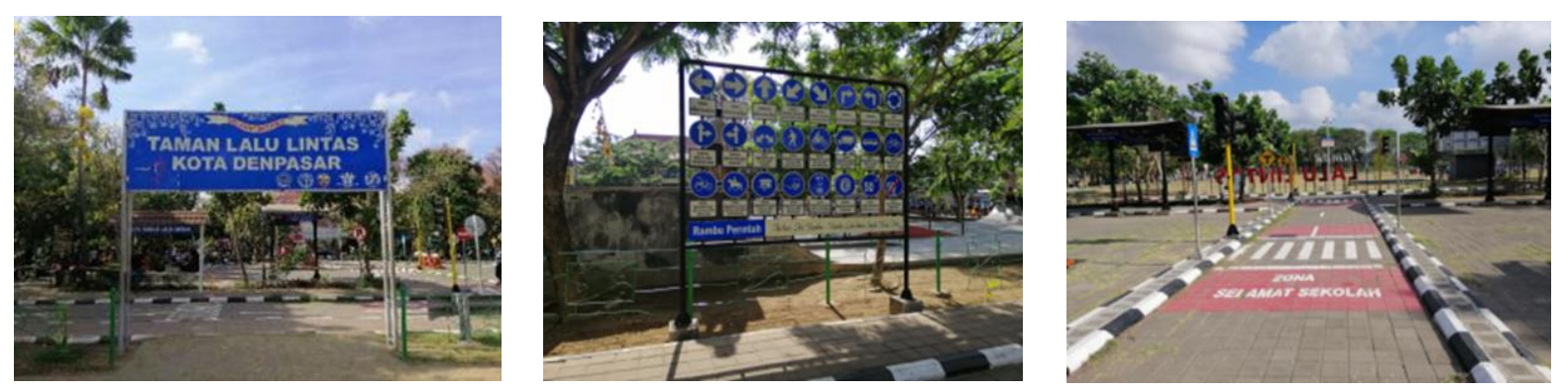

\section{Gambar 1. Taman Lalu Lintas Kota Denpasar}

Tersedianya Taman Lalu Lintas dimanfaatkan sekolah-sekolah PAUD untuk mengedukasi siswa melatih sikap disiplin. Manfaat yang diperoleh dari kegiatan pembelajaran di luar kelas pada Taman Lalu Lintas adalah melatih disiplin siswa, siswa mengetahui tata tertib dan peraturan lalu lintas. TK Gita Sapta Kumara yang dikepalai Ibu Nonik Ariyanti, S.E., S.Pd menjelaskan:

“...Taman Lalu Lintas memberikan banyak manfaat bagi sekolah kami, siswa dapat belajar tentang tertib berlalu lintas. Selain itu, siswa belajar bersikap disiplin, sosial dan mandiri. Pembelajaran di luar kelas memberikan pengetahuan yang lebih mendalam bagi siswa...." (Wawancara, 19 Juli 2019)

Pihaknya menuturkan setelah mengajak anak bermain sambil belajar di Taman Lalu Lintas, siswa TK Gita Sapta Kumara dapat menerapkan disiplin khususnya saat di jalan raya. Anak-anak yang mulanya tidak mengenakan helm ke sekolah meminta kepada orang tuanya untuk dibelikan helm. Bahkan ada anak yang menegur ke orang tuanya saat orang tua siswa melanggar rambu lalu lintas. Tampak antusiasme dan keceriaan anak-anak saat 
proses pembelajaran dilangsungkan di Taman Lalu Lintas. Hal senada juga disampaikan orang tua siswa di TK Gita Sapta Kumara, Ibu Satikayanti memaparkan:

“...sebagai orang tua saya mendukung program sekolah. Apalagi anak-anak tidak hanya belajar di dalam kelas saja. Dengan dibawa ke tempat ini, anak-anak dapat belajar secara langsung mengenai rambu-rambu lalu lintas dan displin..." (Wawancara 19 Juli 2019)

Sekolah lain yang memanfaatkan Taman Lalu Lintas di Kota Denpasar adalah TK Raina Arta Kumara. Ibu Ni Ketut Taman, SPd selaku kepala sekolah mengatakan:

“....Anak-anak dapat mengenal rambu-rambu lalu lintas dan aturan di jalan raya. Menumbuhkan rasa kebersamaan, melatih kedisiplinan saat berada di luar lingkungan sekolah..." (Wawancara, 10 September 2019)

Penjelasan di atas menunjukkan sekolah-sekolah TK/PAUD mendapatkan manfaat dari kegiatan pembelajaran di Taman Lalu Lintas. Meskipun demikian, jumlah sekolah yang memanfaatkan Taman Lalu Lintas masih minim. Hal ini terlihat pada Tabel 1, data dari Dinas Perhubungan Kota Denpasar hanya terdapat 18 sekolah yang mengajukan izin penggunaan Taman Lalu Lintas. Padahal di Kota Denpasar terdapat 324 sekolah TK/PAUD yang tersebar di 4 kecamatan (Kemendikbud, 2019).

Tabel 1 Jumlah Sekolah TK/PAUD yang Memanfaatkan Taman Lalu Lintas Tahun 2018

\begin{tabular}{cll}
\hline No & Bulan & Jumlah sekolah \\
\hline 1. & Januari & 3 \\
2. & Februari & - \\
3. & Maret & 2 \\
4. & April & - \\
5. & Mei & - \\
6. & Juni & 1 \\
7. & Juli & - \\
8. & Agustus & 6 \\
9. & September & - \\
10. & Oktober & 5 \\
11. & November & - \\
12. & Desember & 1 \\
\hline Jumlah & & 18 \\
\hline
\end{tabular}

Sumber: (Perhubungan, 2019)

Hasil pengumpulan data di Taman Lalu Lintas, sebanyak 74\% dari 100 responden responden menyatakan Taman Lalu Lintas mudah dijangkau dari tempat tinggalnya. Sebanyak 78\% dari 100 responden menyukai dan antusias berkunjung ke Taman Lalu Lintas. Hanya $47 \%$ dari responden menyatakan fasilitas toilet yang ada di Taman Lalu Lintas perlu ditingkatkan. Hal ini menunjukkan keberadaan Taman Lalu Lintas memberikan tempat bagi ana-anak khususnya anak usia dini untuk belajar dan memberikan pengalaman langsung dalam prilaku hidup tertib. Penyediaan fasilitas pendukung seperti kamar mandi, tempat peneduh memberikan nilai lebih bagi fungsi Taman Lalu Lintas tersebut.

\section{Taman Janggan}

Taman Janggan diambil dari nama jenis layang-layang tradisional, Janggan. Nama Janggan dipakai karena bentuk taman ini memanjang menyerupai ekor layang-layang Janggan. Taman Janggan diresmikan pada tanggal 6 Januari 2017 oleh Ketut Sudikerta Wakil Gubernur. Pendirian Taman Janggan digagas oleh Pemerintah Pusat melalui Satuan Kerja Penataan Bangunan dan Lingkungan, kemuadian dihibahkan ke Pemerintah Propinsi Bali. 
Pemerintah Propinsi Bali menghibahkan ke Pemerintah Kota Denpasar untuk pemeliharaan di bawah koordinasi Dinas Perumahan, Kawasan Pemukiman dan Pertanahan Kota Denpasar. Tujuan pendirian Taman Janggan dalah untuk memberikan ruang bermain anak yang layak dan representatif di Kota Denpasar. Taman Janggan berlokasi di Jalan Raya Puputan, Kelurahan Renon Denpasar. Lokasi ini dipilih karena memiliki vegetasi yang cukup banyak, rindang, dan dekat dengan Kantor Polisi. (Dinas Perumahan, Kawasan Permukiman dan Pertanahan Kota Denpasar, 2019).

Tahun 2019, dari hasil evaluasi lapangan serta audit yang dilaksanakan Tim Kementerian Pemberdayaan Perempuan dan Perlindungan Anak Republik Indonesia, Taman Janggan masuk dalam kategori "Ruang Bermain Anak (RBA)" tingkat utama dengan skor 398. Kementerian Pemberdayaan Perempuan dan Perlindungan Anak Republik Indonesia memberikan kepercayaan Pemerintah Kota Denpasar mengelola sarana bermain dan rekreasi anak yakni Taman Janggan guna memberikan rasa aman dan nyaman kepada anak yang bermain di taman tersebut. Taman Janggan dilengakapi dengan permainanpermainan yang berstandar internasional dan standar ramah anak sehingga tidak cepat karatan, kuat, dan aman bagi anak-anak. Kepala Seksi Operasional Pemeliharaan Taman Dinas Perumahan, Kawasan Permukiman dan Pertanahan Kota Denpasar, Bapak I Wayan Sudiartha mengatakan:

“....Seluruh mainan yang ada di sana berstandar internasional. Suatu kali ada matras yang sudah rusak, kami harus menunggu lama untuk mengganti karena barangnya tidak ada yang menjual di Bali. Kami menunggu kiriman dari Australia. Kami minta masyarakat untuk menjaga taman dengan cara saat anak-anak bermain sandal ditaruh di rak yang sudah tersedia, sehingga karpet tidak cepat rusak. Bandingkan saja kualitas mainan yang ada di Taman Janggan dengan mainan yang ada di Lapangan Puputan, mainan di Lapangan Puputan lebih cepat karatan dan rusak....."(Wawancara, 28 Agustus 2019)

Pemerintah Kota Denpasar secara berkelanjutan melakukan berbagai upaya, salah satunya dengan melengkapi berbagai fasilitas. Antara lain: area khusus permainan tradisional juga akan melengkapi Taman Janggan yang berada di dalam dan diluar area ruang bermain anak, sesuai dengan ukuran alat permainan tradisonal; ruang jalan masuk tidak adanya parkir dan PKL, kebersihan serta penambahan tanaman. Begitu juga pengecekan dan perawatan RBA, penyediaan tanaman, merapikan sarana prasarana yang tajam agar aman bagi anak-anak. Hal ini dipertegas dengan pernyataan Sudiartha

“....Dinas Perkim menempatkan 2 orang tenaga kebersihan setiap hari untuk merawat tanaman yang ada di Taman Janggan. Pak Walikota sudah menugaskan Dinas Perkim untuk memelihara dan merawat permainan yang ada di sana. Kebersihannya juga kami jaga. Untuk itu kami mengharap agar masyarakat yang memakai turut serta menjaga kebersihan taman...."(Wawancara 28 Agustus 2019)

Fasilitas yang ada di Taman Janggan meliputi 4 buah ayunan, 3 buah perosotan, 2 buah terowongan, 3 buah jungkat-jungkit, 1 buah panjatan, 1 buah pijakan, 1 buah gelantungan, 1 buah area bak pasir, rak sepatu 2 buah, kotak obat, dan 2 buah toilet. Taman Janggan juga dilengkapi dengan CCTV, lampu penerangan, serta tempat parkir untuk disabilitas. Jenis permainan yang ada di Taman Janggan cocok untuk anak berusia 3-6 tahun, dimana pada usia ini membutuhkan tempat bermain sendiri dan bersama teman-temannya untuk bersosialisasi, membutuhkan tempat bermain yang dekat (mudah diakses dengan berjalan kaki atau bersepeda), aman, banyak fasilitas bermain (perosotan, jungkat-jungkit, panjatan, ayunan), menarik dan indah, ada fasilitas untuk pengawasan orang tua, dan gratis (Widyawati, 2015) 

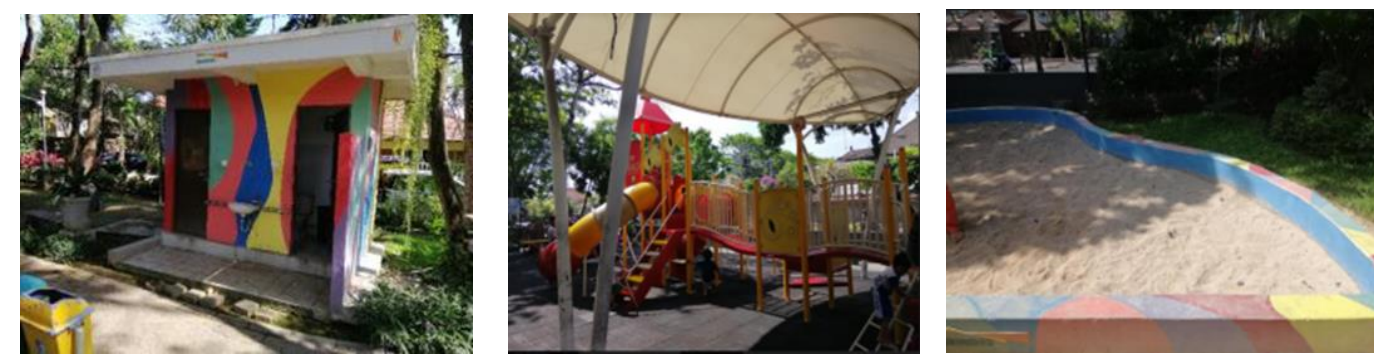

Gambar 2. Fasilitas di Taman Janggan

\section{Peran Ruang Publik Terpadu Ramah Anak Bagi Anak Usia Dini}

Ruang Publik Terpadu Ramah Anak di Kota Denpasar yaitu Taman Lalu Lintas dan Taman Janggan merupakan salah satu lingkungan belajar yang ada di Kota Denpasar. Pembangunan kedua taman dimaksudkan untuk memberikan tempat bermain sambil belajar (edurecreation) yang digunakan warga masyarakat termasuk anak usia dini. Anak usia dini dapat mempelajari lingkungan dari berbagai aspek seperti prosesnya, pemanfaatannya, fungsinya, pemeliharaannya, daya dukungnya, serta aspek lain yang berkenaan dengan pembangunan dan kepentingan masyarakat pada umumnya. Taman Lalu Lintas dan Taman Janggan menciptakan lingkungan yang mampu memberikan kesempatan beraktivitas dan berekreasi secara leluasa, merangsang berbagai indra anak secara baik yang berpengaruh pada perkembangan dan kemajuan belajar anak baik aspek kognitif, afektif, maupun psikomotorik
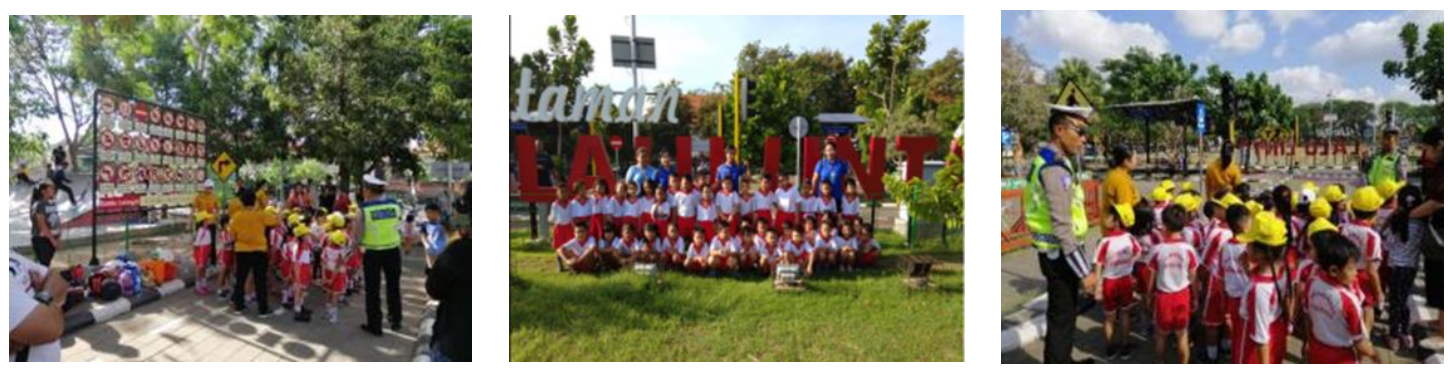

Gambar 3. Aktivitas anak di Taman Lalu Lintas
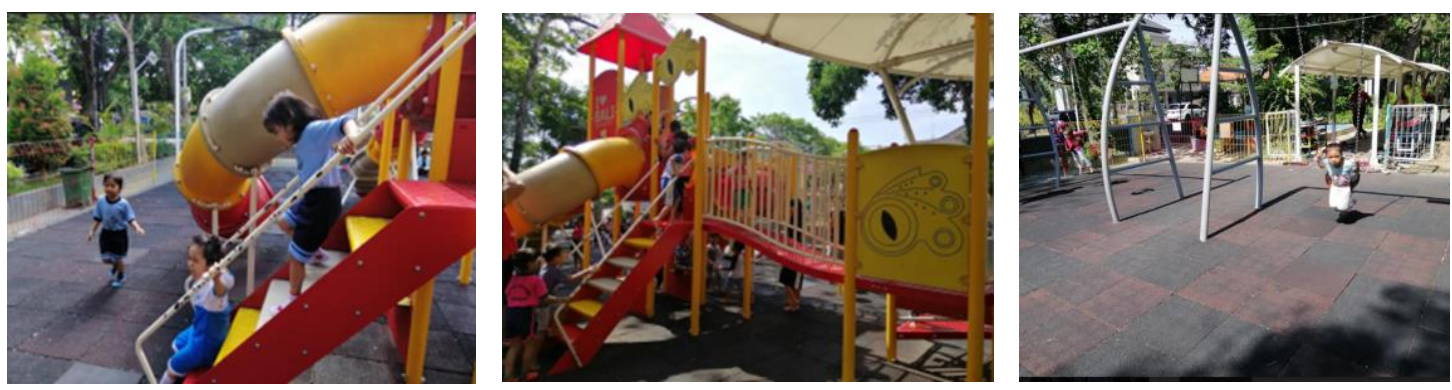

Gambar 4. Aktivitas anak di Taman Janggan

Aktivitas pembelajaran di luar merupakan bagian perkembangan anak yang melibatkan multiaspek perkembangan anak. Multiaspek perkembangan yang dapat ditingkatkan antara lain perkembangan fisik, perkembangan sosial budaya, perkembangan emosional dan intelektual. Anak yang dibesarkan di lingkungan yang kurang menyediakan peralatan, waktu, dan ruang bermain bagi anak, akan menimbulkan aktivitas bermain anak berkurang (Zaini, 2015). Aktivitas di ruang ruangan berperan dalam mengintegrasikan sensoris dan berbagai potensi yang dimiliki anak. Aktivitas pembelajaran di luar ruangan 
merangsang perkembangan dan pertumbuhan fisik (Mariana, Nugraha, \& Rachmawati, 2010).

Menurut Johson dalam (Mariana et al., 2010) ada empat tipe pengalaman bermain yaitu: 1) permainan atau latihan fungsional yang melibatkan praktik dan pengulangan aktivitas motorik kasar; 2) permainan konstruktif yang melibatkan penggunaan materimateri seperti cat atau pasir untuk diciptakan/ dibentuk; 3) permainan drama atau permainan pura-pura yang sering dilaksanakan dalam tempat tertutup; 4) permianan kelompok atau permianan yang melibatkan lebih dari satu orang anak (misalnya jungkat jungkit, permainan yang memiliki aturan, dan permainan drama).

Nilai edukasi yang didapat di Taman Lalu Lintas adalah nilai perkembangan kognitif. Di Taman Lalu Lintas anak dapat belajar tertib berlalu lintas, anak mengetahui arti rambu-rambu lalu lintas, mengetahui cara menyeberang jalan. Selain itu, di Taman Lalu Lintas anak dapat juga belajar warna, bentuk geometri. Menurut Wijayanti, S.Pd:

“...anak-anak dapat belajar tertib berlalulintas. Anak bisa belajar bagaimana menyeberang jalan. Saat akan mengadakan kegiatan outing, minta izin ke Polda Bali agar disiapkan petugas polisi. Selain itu disiapkan sepeda yang bisa dipakai anak untuk belajar tertib di jalan. Anak juga belajar mengenal warna-warna dan bentukbentuk geometri. Ada rambu yang berbentuk lingkaran, segitiga, segiempat....." (Wawancara, 13 Agustus 2019)

Pembelajaran outing class mengajak anak untuk beradaptasi dengan lingkungan, alam sekitar, serta dengan kehidupan masyarakat, bisa mengetahui pentingnya keterampilan hidup dan pengalaman hidup di lingkungan dan alam sekitar (Ulfa, 2014). Vygotsky dalam teori perkembangan kognitif mengungkapkan perkembangan kognitif anak sangat dipengaruhi adanya interaksi sosial antara anak terhadap lingkungannya. Zona perkembangan proksimal yaitu konsep konstruktivisme sosial dimana anak mengembangkan cara-cara baru dalam berpikir dan menyelesaikan masalah dengan bekerja bersama orang lain. (Walujo \& Listyowati, 2017).

Lingkungan alam terbuka yang bebas memberikan kesempatan alamiah anak untuk berlari, melompat, dan menggerakkan seluruh tubuhnya. Kemampuan motorik kasar juga dapat berkembang sesuai dengan tahap perkembangan mereka. Anak dapat merasakan bagaimana rasanya berada di ketinggian saat bermain ayunan, merangkak di dalam terowongan atau meniti pada papan titian. Perkembangan motorik anak terbagi mempunyai pola-pola dasar yaitu pola ceplalocaudal yang merupakan rangkaian pola pertumbuhan paling besar terjadi di bagian atas dan perbedaan yang secara bertahap (Walujo \& Listyowati, 2017).

Bermain di lingkungan terbuka mendorong anak berinteraksi di antara sesama anak, keterampilan sosial, kemampuan bernegosiasi, dan kerja sama. Anak-anak belajar berkompromi seta melatih kesabaran ketika menunggu giliran. Melalui bermain dapat memberi kesempatan bagi anak untuk bereksplorasi, menemukan, mengekspresikan perasaan, berkreasi, dan belajar secara menyenangkan (Kristiawan \& Rozalena, 2017). Melalui bermain dapat melatih keterampilan dan kecerdasan anak, turut memperkenalkan aturan-aturan sosial kepada anak, melatih disiplin diri pada anak (Hastuti, 2009). Hasil observasi di Taman Janggan, jumlah mainan masih terbatas. Hal ini menjadi kendala terutama saat ramai pengunjung sehingga anak-anak harus mengantri dan menunggu giliran untuk memakai. Anak belajar untuk bersabar dan bernegosiasi dengan teman lainnya. Pendapat yang dikemukakan Nonik Ariyanti, S.E., S.Pd ketika mengajak siswanya melakukan kegiatan pembelajaran di Taman Janggan:

“....jumlah mainan di Taman Janggan terbatas, sehingga saat bermain anak-anak belajar sabar menunggu giliran. Anak belajar bersosialisasi berkenalan dengan 
teman baru yang ada di sana. Melakukan kegiatan di Taman Janggan menyenangkan bagi siswa kami...." (Wawancara, 19 Juli 2019)

Bagi anak, kemampuan untuk mengungkapkan perasaannya dapat terjadi secara alami ketika proses pembelajaran di luar ruangan. Ketika di belajar di kelas, anak tidak diperbolehkan untuk berlarian, namun ketika bermain di luar ruangan hal itu diperbolehkan. Anak boleh mengeksplorasi lingkungan belajar di luar kelas tetap dalam pengawasan guru. Kegiatan pembelajaran di luar kelas memberikan anak berinteraksi langsung dengan benda-benda yang ada di sana. Sehingga memberikan kesempatan anak untuk mengembangkan kreativitasnya. Setiap anak terlahir sebagai anak yang kreatif. Namun, apabila diberikan stimulus dan treatement, maka kreativitas anak semakin berkembang. Pengembangan kreativitas yang dilakukan di TK ini bervariasi, namun anak lebih banyak melakukan kegiatan pembelajaran dibandingkan hanya diberikan teori saja. Anak banyak melakukan berbagai percobaan yang dapat menumbuhkembangkan kreativitas mereka (Astuti \& Aziz, 2019). Kreativitas yang dimiliki seorang anak memberikan keterampilannya dalam berpikir (thinking skills). Ketrampilan berpikir yang baik menjadi modal bagi seseorag untuk memecahkan masalah. (Sudarma, 2013). RPTRA berhasil menjadi attachment figure bagi anak, karena RPTRA memiliki kualitas dimensi fisik (place dimension), seperti kemudahan akses dan kedekatan lokasi RPTRA dengan rumah tinggal; ketersediaan fasilitas ruang luar untuk bermain (playground), taman hijau, dsb, serta ketersediaan fasilitas ruang dalam seperti aula/serbaguna untuk belajar dan untuk menampung berbagai aktivitas edukasi dan seni yang rutin diadakan di RPTRA (Prakoso \& Dewi, 2017).

\section{SIMPULAN}

Ruang Publik Terpadu Ramah Anak di Kota Denpasar yaitu Taman Lalu Lintas dan Taman Janggan merupakan salah satu lingkungan belajar yang ada di Kota Denpasar. Pembangunan kedua taman dimaksudkan untuk memberikan tempat bermain sambil belajar (edurecreation) yang digunakan warga masyrakat termasuk anak usia dini. Nilai edukasi di Taman Lalu Lintas dan Taman Janggan yang dapat ditingkatkan antara lain perkembangan kognitif, perkembangan fisik, perkembangan sosial budaya, perkembangan emosional dan intelektual. Sekolah TK/ PAUD memanfaatkan Taman Lalu Lintas dan Taman Janggan untuk kegiatan pembelajaran di luar kelas sebagai salah satu model pembelajaran. Rata-rata kunjungan ke Taman Lalu Lintas dan Taman Janggan sebanyak 2 kali dalam setahun yakni pada kegiatan jeda tengah semester. Keberadaan Taman Lalu Lintas dan Taman Janggan memberikan manfaat bagi sekolah TK/PAUD dan juga masyarakat umum.

\section{UCAPAN TERIMAKASIH}

Terima kasih penulis ucapkan kepada Universitas Dhyana Pura melalui skema hibah penelitian dasar. Ketua dan staff LPPM Universitas Dhyana Pura atas dukungan selama ini. Kaprodi PG-PAUD Universitas Dhyana Pura, mahasiswa, serta semua pihak yang membantu dalam pelaksanaan penelitian ini.

\section{DAFTAR PUSTAKA}

Anhusadar, L. O., \& Islamiyah. (2019). Taman Layak Anak Usia Dini di Kota Kendari. Jurnal Obsesi : Jurnal Pendidikan Anak Usia Dini, 3(1). https://doi.org/10.31004/obsesi.v3i1.106

Astuti, R., \& Aziz, T. (2019). Integrasi Pengembangan Kreativitas Anak Usia Dini di TK Kanisius Sorowajan Yogyakarta. Jurnal Obsesi : Jurnal Pendidikan Anak Usia Dini, 3(2), 294. https://doi.org/10.31004/obsesi.v3i2.99

Desti, R., \& Prihastom, B. (2018). Identifikasi Penerapan Konsep Ruang Publik Terpadu Ramah Anak (RPTRA) Pada Taman Kambang Iwak Palembang. Vitruvian, Jurnal Arsitektur, 
DOI: 10.31004/obsesi.v4i1.396

$$
\begin{aligned}
& \text { BangunanE } \\
& \text { LIngkungan, 8(1), } \\
& \text { https://doi.org/dx.doi.org/10.22441/vitruvian.2018.v8i1.004 }
\end{aligned}
$$

Fadlillah, M. (2012). Desain Pembelajaran PAUD. Yogyakarta: Ar-Ruzz Media.

Hastuti, D. (2009). "Stimulasi Psikososial pada Anak Kelompok Bermain di Kota Bogor dan Pengaruhnya pada Perkembangan Motorik, Kognitif, Sosial Emosi dan Moral/Karakter Anak." Jurnal Ilmu Keluarga Dan Konsumen, 2(1), 41-56. https:/ / doi.org/10.24156/jikk.2009.2.1.41

Herllina, N., \& Nadiroh. (2018). Peran Strategis Ruang Publik Terpadu Ramah Anak Dalam Rangka Pemenuhan Hak Anak Terhadap Lingkungan. Jurnal Pendidikan Usia Dini, 12(104-117). https://doi.org/https://doi.org/10.21009/JPUD.121 09

Hernowo, E., \& Navastara, A. M. (2017). Karakteristik Ruang Publik Terpadu Ramah Anak (RPTRA) Bahari di Kecamatan Cilandak Jakarta Selata. Jurnal Teknis ITS, 6(567-570).

Kristiawan, M., \& Rozalena. (2017). Pengelolaan Pembelajaran Paud Dalam Mengembangkan Potensi Anak Usia Dini. JMKSP (Jurnal Manajemen, Kepemimpinan, Dan Supervisi Pendidikan), 2(1), 76-86.

Latif, M. et al. (2014). Orientasi Baru Pendidikan Anak Usia Dini Teori dan Aplikasinya. Jakarta: Kencana Prenadamedia Grup.

Mariana, R. (2017). Penataan Lingkungan Belajar Terpadu Untuk Meningkatkan Potensi Kecerdasan Jamak Anak. Pedagogia: Jurnal Ilmu Pendidikan, 15(3), 759-767.

Mariana, R., Nugraha, A., \& Rachmawati, Y. (2010). Pengelolaan Lingkungan Belajar. Jakarta: Kencana Prenadamedia Grup.

Perhubungan, D. (2019). Data Kunjungan Sekolah PAUD. Denpasar.

Permendikbud Nomor 146. Kurikulum 2013 Pendidikan Anak Usia Dini (2014).

Prakoso, S., \& Dewi, J. (2017). Rasa Kelekatan Anak Pada Ruang Publik Terpadu Ramah Anak (Rptra). NALARs, 17(1), 1. https:// doi.org/10.24853/nalars.17.1.1-10

Prasetyo, A., Atma, U., \& Yogyakarta, J. (2019). Peningkatan Kualitas Taman Denggung Di Sleman Sebagai Taman Ramah Anak Melalui Pengembangan Kecerdasan Anak, 209-215.

Rizani, E. N., Wulandari, A., Hernovianty, F. R., Perencanaan, J., Fakultas, K., Universitas, T., ... Universitas, T. (2017). Klasifikasi Ruang Terbuka Hijau Taman Layak Anak Di Kota Pontianak, 2-5.

Santyasa, I. W. (2007). Model-Model Pembelajaran Inovatif. In Makalah pelatihan tentang Penelitian Tindakan Kelas bagi Guru-Guru SMP dan SMA di Nusa Penida. Bali. Retrieved from http://www.ncbi.nlm.nih.gov/pubmed/7465931

Sudarma, M. (2013). Mengembangkan Keterampilan Berpikir Kreatif (1st ed.). Jakarta: RajaGrafindo Perkasa.

Tarigan, L. A. (2018). Keamanan Dan Keselamatan Anak Pada Ruang Publik Terpadu Ramah Anak Kalijodo Di Jakarta. Jurnal Mahasiswa Jurusan Arsitektur, 6(3). Retrieved from http://arsitektur.studentjournal.ub.ac.id/index.php/jma/article/view/654

Ulfa, D. M. (2014). Pengaruh Pembelajaran Berwawasan Lingkungan Sebagai Sarana Meningkatkan Kecerdasan Naturalis Pada Anak Usia 5-6 Tahun Di TK Pertiwi Kecamatan Gunungpati Semarang. BELIA: Early Childhood Education Papers, 3(2), 23-30. Retrieved from https://journal.unnes.ac.id/sju/index.php/belia/article/view/3718

UU No 20 Tahun 2003. Sistem Pendidikan Nasional (2003).

Walujo, D. A., \& Listyowati, A. (2017). Kompendium PAUD. Depok: Prenadamedia Group.

Widyawati, K. (2015). Penilaian Ruang Bermain Anak Di Kota Depok. Factor Exacta, 8(3), 195-207.

Wondal, R. (2015). Meningkatkan Kemampuan Bercerita Anak Melalui Metode Karya Wisata. Pendidikan Anak Usia Dini, 9(1), 1-14. https://doi.org/DOI: https://doi.org/10.21009/JPUD.091DOI: https://doi.org/10.21009/JPUD.091.01

Yati, P. (2016). Pendidikan Karakter Anak Usia Dini Melalui Metode Pembelajaran Field Trip. Lentera, XVIII(1), 123-139.

Zaini, A. (2015). Bermain sebagai metode pembelajaran bagi anak usia dini. Thufula, 3(1), 118-134. 